\title{
İNTERNET BAĞIMLILIĞININ ONLINE KOMPULSİF VE ONLINE ANLIK SATIN ALMA DAVRANIŞLARINA ETKİSİ
}

\author{
Volkan YAKIN*, Pınar AYTEKİN**
}

\section{öz}

Bu çalışmanın amacı internet bağımlılı̆ının çevrimiçi "kompulsif ve anlık satın alma" davranışlarına etkisi olup olmadığını belirlemektir. Çalışmanın bir diğer amacı çevrimiçi anlık satın alma davranışının çevrimiçi kompulsif satın alma davranışı üzerindeki etkisini ölçmektir. Çalışmada ayrıca, demografik faktörlere göre; internet bağımlılığı, çevrimiçi anlık satın alma davranışı ve çevrimiçi kompulsif satın alma davranışı açısından farklılıklar incelenmiştir. 405 katılımcıya uygulanan anket sonuçları; internet bağımlıı̆ının çevrimiçi "kompulsif ve anlık satın alma" davranışları üzerinde pozitif yönde bir etkisi olduğunu göstermiştir.

Anahtar Sözcükler: Internet bağımlıĬı̆, Online kompulsif satın alma davranışı, Online anlık satın alma davranışı

\section{THE EFFECT OF INTERNET ADDICTION ON ONLINE COMPULSIVE AND ONLNE IMPULSIVE PURCHASE BEHAVIOR \\ ABSTRACT}

The purpose of this study is to determine whether internet addiction has an effect online "compulsive and impulsive buying" behaviors. Also to measure the effect of online impulsive buying behavior on online compulsive buying behavior is the other aim of the research. In this study, we also examined the differences in terms of internet addiction, online "impulsive buying behaviors and compulsive buying" behaviors according to demographic factors. According to the findings of the survey with 405 participant, internet addiction have a positive effect on the online compulsive and online impulsive buying behaviors.

Keywords: Internet addiction, Online compulsive buying behaviour, Online impulsive buying behaviour

\footnotetext{
* Bolu Abant İzzet Baysal Üniversitesi, Gerede Uygulamalı Bilimler Yüksekokulu, Pazarlama Bölümü, Bolu, E-posta: volkanyakin@yahoo.com,

(iD) https://orcid.org/0000-0001-6518-8348

** İzmir Demokrasi Üniversitesi, İktisadi ve İdari Bilimler Fakültesi, İşletme

Bölümü, İzmir, E-posta: aytekinp@yahoo.com,

(iD) https://orcid.org/0000-0003-4313-1927
} 


\section{İnternet Bağımlılığının Online Kompulsif ve Online Anlık Satın Alma Davranışlarına Etkisi}

\section{GİRİş}

Son yıllarda tüketici davranışlarının rasyonel olmadığı gerçeği çok sık ifade edilmeye başlanmıştır. Post modern tüketicilerin satın alma kararlarını verirken bilişsel değerlendirmelerden bağımsız hareket etmeleri sonucunda kompulsif ve anlık satın alma gibi dürtüsel satın alma davranışları ortaya çıkmaktadır. Kompulsif satın alma davranışı, "bireyin dürtüsel olarak satın alma güdüsü hissetmesi ve bunu denetleyememesi sonucunda ortaya çıkan ve maddi olarak zorluklara neden olan bir rahatsızlıktır" (Korur ve Kimzan, 2016: 45). "Dürtüsel olarak kontrol edilemeyen ve üst üste tekrarlanan kompülsif satın alma davranışının ticari amaçlı internet siteleri aracılığıyla gerçekleştirilmesine sanal kompülsif satın alma davranışı denilmektedir" (Zeren ve Gökdağlı, 2017: 42). Anlık satın alma ise, bir tüketicinin hemen bir şey satın almak için anlık, genellikle güçlü ve ısrarcı bir dürtü yaşadığı zaman ortaya çıkar (Rook, 1987). Anlık satın alma davranışına tüketicilerin içinde bulundukları ruh hali ve çevresel etkenlerin neden olduğu belirlenmiştir (Dursun ve Yener, 2014). Online anlık satın alma davranışı ise satın alma niyeti veya düşüncesi içinde olmayan bireyin, online çevreden kaynaklanan dışsal uyaranlara gösterdiği zihinsel bir reaksiyon olarak satın alma eylemini gerçekleştirmesi olarak tanımlanmaktadır (Chen ve Zang, 2015). İçinde bulunduğumuz çağın sunduğu teknolojik kolaylıklar ve dolayısıyla tüketim alışkanlıklarında meydana gelen değişimler kompulsif ve anlık satın alma davranışları için de yeni mecralar oluşmasına sebep olmuştur. Özellikle yeni ekonomide bilgi işlem ve internet teknolojileri tüketiciler için elverişli bir pazar yeri oluşturmuştur. Online satış söz konusu olduğunda mal/hizmet üreticilerinin veya aracıların hedefledikleri pazar bölümüne yönelik pazarlama stratejileri geliştirebilmeleri için ellerinde oldukça fazla araç bulunmaktadır. Bu durum online anlık ve online kompulsif satın alma davranışını artıran gözlemlenebilir bir nedendir.

Diğer taraftan çevrimiçi kompulsif ve çevrimiçi anlık satın alma davranışını etkileyebilecek bir diğer unsur da internet bağımlıı̆ıdır. "İnternet bağımlılı̆ı, genel olarak internetin aşırı kullanılması isteğinin önüne geçilememesi, internete bağı olmadan geçirilen zamanın önemini

1 Bu makale, 26-27 Nisan 2018 tarihlerinde İstanbul'da gerçekleştirilen "Uluslararası Sosyal Araştırmalar Kongresi" adlı kongrede (özet) sözlü bildiri olarak sunulmuştur. 


\section{Volkan Yakın ve Pınar Aytekin}

yitirmesi, yoksun kalındığında aşırı sinirlilik hali ve saldırganlık olması ve kişinin iş, sosyal ve ailevi hayatının giderek bozulması olarak tanımlanabilir" (Arısoy, 2009).

Bu araştırmanın amacı, tüketicilerin daha fazla çevrimiçi olmalarına sebebiyet veren internet bağımllı̆̆ının çevrimiçi anlık satın alma ve çevrimiçi kompulsif satın alma davranışı üzerinde etkisi olup olmadığını ortaya koymaktır. Her yirmi kişiden biri yaşamının bir döneminde kompulsif satın alma davranışı nedeniyle iş ve sosyal yaşamlarının sekteye uğraması sonucu bir takım takım sıkıntılar yaşamaktadır (Maraz, Griffiths ve Demetrovics, 2016). Yapılan araştırmalar bir çeşit internet bağımlıı̆ı olarak da değerlendirilen sosyal medya kullanımı ile ani ve kompulsif satın alma davranışları arasındaki pozitif ilişkiye vurgu yapmaktadır (Lejoyeux ve Weinstein, 2010; Sharif ve Khanekharab, 2017). Diğer taraftan kompulsif satın alma ve anlık satın alma hakkında çok sayıda araştırma olmakla birlikte, doğrudan çevrimiçi kompulsif ve çevrimiçi anlık satın alma davranışlarının anlaşılmasını amaçlayan ve internet bağımlılı̆ı ile olan ilişkisini açıklamaya yönelik çok az sayıda çalışma bulunmaktadır. Bu çalışmalarda da internet kullanım alışkanlıkları/bağımlııkları ile çevrimiçi kompulsif satın alma davranışı ve çevrimiçi anlık satın alma eğilimi arasında pozitif yönlü ilişkiler bulgulanmıştır (Trotzke, Starcke, Müller ve Brand, 2015; Sun ve Wu, 2011). "internet bağımlılı̆ı" bağımsız değişkeninin "çevrimiçi kompulsif" ve "çevrimiçi anlık" satın alma davranışlarına etkisini belirlemeye yönelik henüz çok az sayıda çalışma yapılmış olması göz önünde bulundurulduğunda bu araştırmanın amacının önemi daha iyi anlaşılmaktadır. İIgili yazında görülen sonuçların netleştirebilmesi için bu konunun daha etraflıca araştıııması gerektiği görülmektedir ve bu gereklilik çalışmanın gerçekleştirilmesinde önemli bir motivasyon olmuştur. Araştırmada ayrıca tüketicilerin demografik özellikleri açısından internet bağımlıı̆ı, çevrimiçi anlık ve çevrimiçi kompulsif satın alma davranışlarının farkılık gösterip göstermediği de belirlenmeye çalışılacaktır. Araştırmanın bir diğer amacı da, dürtüsel davranışların kompulsif davranışlar üzerinde etkili olabileceği düşüncesinden yola çıkarak, çevrimiçi anlık satın alma davranışının çevrimiçi kompulsif satın alma davranışı üzerindeki etkisini saptamaktır.

\section{Çevrimiçi Kompulsif Satın Alma Davranışı}

Psikiyatri, psikoloji, ekonomi ve pazarlama bilimlerinin ortak kümesini oluşturan bir konu olan kompulsif satın alma, bir kişinin sonucunda kendisine ve diğer kişilere zarar verecek olan davranışları 


\section{İnternet Bağımlılığının Online Kompulsif ve Online Anlık Satın Alma Davranışlarına Etkisi}

tekrarlamasına öncülük eden bir his, madde veya faaliyet deneyimine sahip olmak veya kullanmakla ilişkili kontrol edilemeyen bir dürtü veya arzuya verilen tepki olarak tanımlanmaktadır (O'Guinn ve Faber, 1989). Çevrimiçi kompulsif satın alma davranışı, alıverişin gerçekleştiği ortamın dijital olması nedeniyle genel kompulsif satın alma davranışından ayrışmakta, ancak davranışa etki eden faktörler açısından benzerlik göstermektedir.

Kompulsif satın alma davranışı gösteren tüketicilerin bu davranışı göstermeyen tüketicilere oranla daha fazla satın alma isteği duydukları, yine diğer tüketicilerle kıyaslandıklarında bu isteklerine karşı düşük bir direnç gösterdikleri belirlenmiştir. Bu durumun ardında öncelikli olarak anksiyeteden kaçınma ve bir rahatlama amacı olduğu anlaşılmaktadır (Scherhorn, Reisch ve Raab, 1990). Kompulsif satın alma davranışının ardında yatan diğer başlıca nedenler arasında kredi kartı kullanımı, kişinin içinde bulunduğu duygu durumu, demografik ve kişilik özellikleri ve internet kullanımı gelmektedir (Arslan, 2015; D'Astous, Maltais ve Roberge, 1990; Faber ve O'Guinn, 1992; Lucas ve Koff, 2014; RodríguezVillarino, González-Lorenzo, Fernández-González, Lameiras-Fernández ve Foltz, 2006; Wang ve Yang, 2008).

Bugüne dek yapılmış çeşitli araştırmalar düzenli kredi kartı kullanımının ve kredi kartlarının limit düzeylerinin kompulsif satın alma ile bağlantılı değişkenler olduğunu ortaya koymaktadır (Arslan, 2015; Phau ve Woo, 2008; Pirog ve Roberts, 2007). Düşük gelirli tüketicilere gelirlerinden fazla harcama imkânı sunması ve güvenle alışveriş yapılmasına izin vermesinin yanı sıra bir statü göstergesi olması gibi nedenlerle kredi kartı kullanımı, tüketicilerin kompulsif satın alma davranışına etki ettiği belirtilmektedir (Arslan, 2015; Joji ve Raveendran, 2008; Norum, 2008). Duygu durumu ise kişinin içinde bulunduğu kaygı, üzüntü, öfke, mutluluk, huzur, yalnızlık, iyimserlik gibi ruh hali veya takındığı tutumları ifade eder (Richins, 1997). Araştırmalarda duygu durumu negatif ve pozitif olmak üzere iki ayrı kategoride ele alınmaktadır. Yapılan çalışmalar yoğun olarak negatif duygu durumları ile kompulsif satın alma ile arasında bir ilişki olduğunu ortaya koymaktadır (Dittmar, Long ve Bond, 2007; Faber ve Christenson, 1996). Araştırmalar çeşitli kişilik özellikleriyle kompulsif bozukluklar arasında da bir ilişki olduğunu ortaya koymakla birlikte kompulsif satın alma davranışılla en tutarlı ve güçlü ilişki gösteren kişilik özelliklerinin başında düşük özgüven, içe dönüklük ve heyecan arayışı özelliklerinin geldiği bulgulanmıştır (Workman ve Paper, 2010). 


\section{Volkan Yakın ve Pınar Aytekin}

Demografik faktörler kişilerin kompulsif satın alma davranışına etki eden faktörler arasında yer almaktadır. Günümüze dek yapılan çalışmalar ağırlıklı olarak kadınların, erkeklere oranla daha fazla kompulsif satın alma davranışı gösterdiğini ortaya koymaktadır (D'Astous vd., 1990; Faber ve O'Guinn 1992; O'Guinn ve Faber, 1989). Gelir durumuna ilişkin erken dönem çalışmalarda anlamlı farklııklar çıkmamışsa da son dönem çalışmalarda sıklıkla düşük gelir grubundaki tüketicilerin kompulsif satın alma davranışını daha fazla gösterdikleri belirlenmiştir. Yaş faktörünün kompulsif satın alma davranışına yönelik ilişkisi ile ilgili ise tutarlı ve net bir sonuç ortaya konulamamışıı (Workman ve Paper, 2010). Çevrimiçi kompulsif satın alma davranışıyla ilgili ise çok az sayıda çalışmaya rastlanmışır (Sharif ve Khanekharab, 2017; Sharif ve Yeoh, 2018; Lee ve Park, 2008). Sharif ve Khanekharab (2017) ve Sharif ve Yeoh (2018), sosyal ağları aşıı kullanan gençlerin daha fazla çevrimiçi kompulsif satın alma eğiliminde olduklarını belirlemişlerdir. Lee ve Park'a (2008) göre ise, internetteki sanal topluluklar tüketicilere hem bilgi vermekte hem de onların çevrimiçi kompulsif satın alma davranışı göstermelerini önlemektedir.

$\mathrm{Bu}$ konuda az çalışmanın olması nedeniyle, çevrimiçi kompulsif satın alma davranışılla ilgili olarak, özelikle demografik faktörler açısından daha fazla bilgiye intiyaç vardır. Bu noktadan hareketle aşağıdaki hipotezler geliştirilmiştir:

H1: Tüketicilerin demografik özelliklerine göre çevrimiçi kompulsif satın alma davranışları arasında anlamlı bir farklııı vardır.

H1a: Tüketicilerin cinsiyetlerine göre çevrimiçi kompulsif satın alma davranışları arasında anlamlı bir farklılık vardır.

H1b: Tüketicilerin medeni durumlarına göre çevrimiçi kompulsif satın alma davranışları arasında anlamlı bir farklılık vardır.

H1c : Tüketicilerin yaşlarına göre çevrimiçi kompulsif satın alma davranışları arasında anlamlı bir farklıık vardır.

H1d: Tüketicilerin kişisel aylık gelirlerine göre çevrimiçi kompulsif satın alma davranışları arasında anlamlı bir farklılık vardır.

H1e: Tüketicilerin mesleklerine göre çevrimiçi kompulsif satın alma davranışları arasında anlamlı bir farklıık vardır.

H1f: Tüketicilerin eğitim düzeylerine göre çevrimiçi kompulsif satın alma davranışları arasında anlamlı bir farklıık vardır. 


\section{Internet Bağımlılığının Online Kompulsif ve Online Anlık Satın Alma Davranışlarına Etkisi}

\section{Çevrimiçi Anlık Satın Alma Davranışı}

Anlık satın alma, genellikle aniden ortaya çıkan bir dürtüyle, zevk ve heyecan gibi duygusal durum ve hislerin eşlik ettiği programsız bir satın alma eylemi olarak tanımlanmaktadır (Rook, 1987). Anlık satın alma, masum bir düzeyden kişinin yaşamını zora sokacak boyutlara kadar eriştiği görülebilen rasyonel olmayan bir tüketici davranışıdır (Verplanken ve Herabadi, 2001). Çevrimiçi anlık satın alma davranışında da, çevrimiçi kompulsif satın alma davranışında olduğu gibi, satın alma eylemi dijital ortamda gerçekleşmekte ancak dürtüye neden olan uyaranların niteliği dışında nedenleri diğer anlık satın alma davranışlarının nedenleriyle benzerlik göstermektedir.

Anlık satın alma davranışının ardında yatan nedenler iki ana başıkta ele alınmaktadır. Bunlardan ilki tüketicinin ani karar vermesine neden olan uyaranlara ilişkin ürün, reklam ve diğer pazarlama karması unsurları gibi nispeten somut faktörlerken bir diğeri ise tüketicinin içinde bulunduğu ruh haline ilişkin ve hedonik zevkleri tatmine yönelik duygusal ve soyut faktörlerdir (Aytekin ve Ay, 2015). Stern (1962), dört tip anlık satın alma davranışından bahsetmektedir: (1) Saf dürtüsel alım, (2) Hatırlatıcı etkisiyle ortaya çıkan anlık satın alma davranışı, (3) Öneriyle ortaya çıkan anlık satın alma davranışı, (4) Planlanmış anlık satın alma davranışı. Saf ve planlı anlık satın alma davranışları iki karşı uçta yer almaktadır. Saf anlık satın alma davranışı genellikle sorunlardan kaçınma, yenilik ve heyecan arayışı gibi duygusal nedenlerle ortaya çıkarken, planlı anlık satın alma hali hazırda alışveriş yapmakta olan tüketicinin alışveriş ortamındaki promosyonların etkisiyle dürtüsel bir alışveriş yapması anlamına gelmektedir. Diğer taraftan, hatırlatıcı ve öneri etkisiyle gerçekleşen anlık satın almalar da davranışın gerçekleşme nedeni açısından planlı satın almayla benzerlik göstermekle birlikte aralarında önemli ayrımlar bulunmaktadır. Reklamlarda ihtiyaç duyulan bir ürünü görüp dürtüsel bir satın alma eylemi hatırlatıcı anlık satın almaya, bir ürünü ilk defa gördükten veya tüketiciye önerildikten sonra ona olan intiyacın farkına varılarak gerçekleşen satın alma davranışı ise öneriyle ortaya çıkan anlık satın alma davranışına örnek teşkil etmektedir. Tablo 1 'de kompulsif ve anlık satın alma davranışları arasındaki farklar görülmektedir. 
Tablo 1: Kompulsif Satın Alma ve Anlık Satın Alma Davranışları Arasındaki Farklar

\begin{tabular}{|c|c|c|}
\hline & $\begin{array}{l}\text { Anlık Satın Alma } \\
\text { Davranışı }\end{array}$ & $\begin{array}{l}\text { Kompulsif Satın Alma } \\
\text { Davranışı }\end{array}$ \\
\hline Tanım & $\begin{array}{l}\text { Güçlü ve bazen karşı } \\
\text { koyulamayan; üzerinde } \\
\text { düşünmeden ani bir satın } \\
\text { alma eyleminin } \\
\text { gerçekleşmesi. }\end{array}$ & $\begin{array}{l}\text { Bir kişinin sonucunda } \\
\text { kendisine ve diğer kişilere } \\
\text { zarar verecek olan } \\
\text { davranışları tekrarlamasına } \\
\text { öncülük eden bir his, madde } \\
\text { veya faaliyet deneyimine } \\
\text { sahip olmak veya kullanmakla } \\
\text { ilişkili kontrol edilemeyen bir } \\
\text { dürtü veya arzuya verilen } \\
\text { tepki. }\end{array}$ \\
\hline $\begin{array}{l}\text { Odak } \\
\text { Noktası }\end{array}$ & Fiziksel Nesne & Tüketim Tecrübesi \\
\hline Etkenler & $\begin{array}{l}\text { * Yeterli zamana sahip olmak } \\
\text { * Yeterli paraya sahip olmak } \\
\text { * Pozitif duygu durumları } \\
\text { * Düşük fiyatlı/indirimli } \\
\text { ürünler } \\
\text { * İçten gelen anlık istek } \\
\text { * Fiziksel yakınlık } \\
\text { * Hızlı elde edilen haz }\end{array}$ & $\begin{array}{l}\text { * Negatif duygu durumları } \\
* \text { Kaçış ihtiyacı } \\
* \text { Hayalperestlik } \\
* \text { Düşük öz-saygı }\end{array}$ \\
\hline Sonuçlar & $\begin{array}{l}\text { Negatif: } \\
\text { * Satın alma sonrası finansal } \\
\text { sorunlar } \\
\text { * Ürünle ilgili hayal kırıklığı } \\
\text { yaşamak } \\
\text { * Suçluluk } \\
\text { * Kontrolü kaybetme hissi } \\
\text { Pozitif: } \\
\text { * Sosyal onay } \\
\text { * Olumlu duygu etkisi } \\
\text { * Hedonik tatmin }\end{array}$ & $\begin{array}{l}* \text { Olumsuz duyguların } \\
\text { yoğunlaşması } \\
* \text { Yüklü borç } \\
* \text { Sekteye uğrayan kişisel } \\
\text { ilişkiler } \\
* \text { Aşırı ürün sahibi olma } \\
* \text { Sosyal dışlanma }\end{array}$ \\
\hline
\end{tabular}

Anlık satın alma ve demografik faktörler arasındaki ilişkiyi araştıran çalışmalarda Awan ve Fatima (2014), Rana ve Tirthani (2012) yaş ve anlık satın alma arasında ters yönlü bir ilişki olduğunu ve cinsiyet ile anlık satın alma arasında anlamlı bir farklııık olmadığını bulgulamıştır. Bununla birlikte cinsiyet ve anlık satın alma davranışı arasında farklııılar 


\section{İnternet Bağımlılığının Online Kompulsif ve Online Anlık Satın Alma Davranışlarına Etkisi}

bulgulayan çalışmalar da bulunmaktadır (Muruganantham ve Bhakat 2013; Dittmar, Beattie ve Friese, 1995). Awan ve Abbas (2015) gelir ve anlık satın alma davranışı arasında güçlü bir ilişki olduğunu belirlemişlerdir. Bu bilgilerden yola çıkılarak aşağıdaki hipotezler geliştirilmiştir.

H2: Tüketicilerin demografik özelliklerine göre çevrimiçi anlık satın alma davranışları arasında anlamlı bir farklılık varıdır.

H2a: Tüketicilerin cinsiyetlerine göre çevrimiçi anlık satın alma davranışı arasında anlamlı bir farklılık varıdır.

$\mathrm{H} 2 \mathrm{~b}$ : Tüketicilerin medeni durumlarına göre çevrimiçi anlık satın alma davranışları arasında anlamlı bir farklılık vardır.

H2c: Tüketicilerin yaşlarına göre çevrimiçi anlık satın alma davranışları arasında anlamlı bir farklıık vardır.

H2d: Tüketicilerin kişisel aylık gelirlerine göre çevrimiçi anlık satın alma davranışları arasında anlamlı bir farklıık vardır.

H2e: Tüketicilerin mesleklerine göre çevrimiçi anlık satın alma davranışları arasında anlamlı bir farklılık vardır.

H2f: Tüketicilerin eğitim düzeylerine göre çevrimiçi anlık satın alma davranışları arasında anlamlı bir farklılık vardır.

\section{İnternet Bağımlılığı}

İnternet günümüzün en önemli teknolojik gelişmelerinden biridir. İnternet kullanımına ilişkin yapılan güncel araştırma verilerine göre dünya nüfusunun yarısından çoğu, ülkemizde ise nüfusun $\% 80^{\prime} \mathrm{i}$ internet erişimine sahiptir (Internetworldstats, 2017; Cnnturk, 2018). İnternetin kullanıcılarına sunduğu hayatı kolaylaştıran çok çeşitli hizmetlerin olması ve bu hizmetlere erişim oranının bu kadar yüksek olması toplumsal ve bireysel yaşamın dinamiklerinde de önemli bir takım değişimlere neden olmaktadır. İnternetin yaygınlaşmasıyla ilişkili olarak internet bağımlıı̆ı da çağımızın, insan davranışı üzerinde yıkıcı etkilere neden olabilen sorunlarından biri olarak literatürde giderek daha fazla üzerinde durulan bir kavram olmaya başlamıştır. Özellikle bir internet bağımlılık çeşidi olarak değerlendirilen "internet oyun bağımlıı̆ı"nın çok önemli bir sorun olduğu 2016 yılında, ruhsal hastalıkların sınıflandırımasında kullanılan Psikiyatrik Sınıflandırma Sistemi Tanı Listesi'ne (DSM) zihinsel rahatsızlık olarak girmesiyle daha net bir şekilde anlaşılmıştır (Bozkurt, Şahin ve Zoroğlu, 2016).

İnternet bağımlıı̆ı kavramının ilk olarak Goldberg (1995) ve Young (1996) tarafından tartışmaya açıldığı bilinmektedir (Dalal ve Basu, 2016). 


\section{Volkan Yakın ve Pınar Aytekin}

Young (1998) internet bağımlılığını, bir ilaç veya alkole bağımlı olma durumuna benzer nitelikte bir bağımlıık olarak tanımlamıştır. Griffiths (1999), internet bağımlılı̆ını teknolojik bağımlıı̆ın bir alt çeşidi olarak değerlendirmiştir. Teknolojik bağımlılık ise kimyasal bir maddeye bağımlı olmadan insan-makine etkileşimine bağlı olarak ortaya çıkan davranışsal bir bağımlılıktır (Griffiths, 1999). Tablo 2'de internet bağımlılığının davranışsal, mental ve sosyal etkiler açısından gösterdiği belirtiler özetlenmiştir.

\section{Tablo 2: İnternet Bağımlılığının Etkileri}

\begin{tabular}{|c|c|}
\hline Kategori & Belirtiler \\
\hline Davranışsal & $\begin{array}{l}\text { - Çevrimiçi ortamda dikkat çekecek ölçüde giderek daha } \\
\text { - } \quad \text { Nazla vakit geçirme intiyacı (Tolerans) } \\
\text { - İnternet ile ilişkili faaliyetlere harcanan zamanda büyük } \\
\text { bir artış } \\
\text { - İnternet kullanım derecesi hakkında yalan söylemek } \\
\text { - Zihnin sürekli internet faaliyetleriyle meşgul olması } \\
\text { - İnterneti sorunlardan kaçmak için kullanmak } \\
\text { - Yaşanan fiziksel, sosyal, mesleki veya psikolojik } \\
\text { sorunların internet kullanımından kaynaklanıyor } \\
\text { olabileceği bilgisine sahip olunmasına rağmen interneti } \\
\text { kullanmaya devam etmek }\end{array}$ \\
\hline $\begin{array}{l}\text { Fiziksel ve } \\
\text { Mental }\end{array}$ & $\begin{array}{l}\text { - Çekilme (yoksunluk) sendromu: internet kullanımını } \\
\text { azaltmanın anksiyete ile sonuçlanması, takıntılı şekilde } \\
\text { internet düşünmek ve internet ile ilgili hayaller kurmak. } \\
\text { - İnternet kullanımını kontrol etme veya azaltmaya karşı } \\
\text { sürekli bir istek duymak } \\
\text { - Kan basıncının yükselmesi, kardiyovasküler stres, } \\
\text { hafıza sorunları, konsantrasyon eksikliği, baş ağrısı, } \\
\text { mide ve kas ağrısı ve görmenin zayıflaması } \\
\text { - Uyuşukluk, halsizlik, uykusuzluk, panik, sinirlilik ve öfke }\end{array}$ \\
\hline Sosyal Etki & $\begin{array}{l}\text { - İnternet kullanımı nedeniyle önemli sosyal, mesleki } \\
\text { veya eğlence faaliyetlerinden vazgeçmek } \\
\text { - } \quad \text { İşyerinde rekabet ve gerilimde artış; verimlilikte azalma } \\
\text { - } \quad \text { Daha uzun çalışma günleri ve daha az boş vakit }\end{array}$ \\
\hline
\end{tabular}

Kaynak: Sally, (2006: 6).

İnternet kullanımı ve demografik faktörler arasındaki ilişkiyi araştıran bazı çalışmalarda erkeklerin kadınlardan (Young, 1998; Servidio, 2014; Hur, 2006) gençlerin yetişkinlerden daha fazla internet bağımlısı oldukları bulgulanmıştır (Young, 1998; Servidio, 2014; Ferraro, Caci, D'amico ve Blasi, 2006). Bununla birlikte bazı çalışmalarda erkeklerin 


\section{İnternet Bağımlılığının Online Kompulsif ve Online Anlık Satın Alma Davranışlarına Etkisi}

kadınlardan daha fazla bağımlı oldukları sonucu elde edilirken (Tsai, Cheng, Yeh, Shih, Chen, Yang ve Yang, 2009) bazı çalışmalarda ise cinsiyet ve internet bağımılı̆̆ı arasında anlamlı farklılıklar bulunamamıştır (Ferraro vd., 2006). Sosyal olarak yalnız olanların ise internette daha fazla vakit geçirdikleri belirlenmiştir (Kim, LaRose ve Peng, 2009). Bu bilgiler ışığında aşağıdaki hipotezler geliştirilmiştir:

H3: Tüketicilerin demografik özelliklerine göre internet bağımlılı̆ı davranışları arasında anlamlı bir farklılık vardır.

H3a: Tüketicilerin cinsiyetlerine göre internet bağımlılığı davranışları arasında anlamlı bir farklılık vardır.

H3b: Tüketicilerin medeni durumlarına göre internet bağımlılığı davranışları arasında anlamlı bir farkılık vardır.

H3c: Tüketicilerin yaşlarına göre internet bağımlılığı davranışları arasında anlamlı bir farklılık vardır.

H3d: Tüketicilerin kişisel aylık gelirlerine göre internet bağımlıı̆ı davranışları arasında anlamlı farklııı vardır.

H3e: Tüketicilerin mesleklerine göre internet bağımlılığı davranışları arasında anlamlı bir farklılık vardır.

H3f: Tüketicilerin eğitim düzeylerine göre internet bağımlılığı davranışları arasında anlamlı bir farkııık vardır.

Aşırı internet kullanımı üzerine yapılan araştırmalar internet bağımlılarının, anksiyete ve yalnızlık hissi gibi olumsuz duygularla baş edebilmek için ve aynı zamanda kendi kimliklerini yansıtabilecek ortamlar sunduğu için vakitlerinin çoğunu sosyal medya sitelerinde geçirdiklerini göstermektedir (Caplan, 2006; Sharif ve Yeoh, 2018). İnternet bağımlıı̆ına zemin hazırlayan sosyal medya sitelerinin firmalara, kullanııların ilgi alanlarını belirleme ve pazarlama iletişimlerini bölümlendirme yolunda kolaylık sağladıkları göz önünde bulundurulduğunda internet bağımlıı̆ının çevrimiçi anlık satın alma ve çevrimiçi kompulsif satın alma davranışını arttıracağı öngörülmektedir. Lejoyeux ve Weinstein (2010), doğrudan yüz yüze iletişim kurmayı gerektirmemesi, alışveriş işlemlerinin mahremiyetine izin vermesi ve ürün/ fiyat önerilerinin dijital ortamda sunulması gibi nedenlerle internet kullanımının kompulsif satın almayı arttırabileceğini belirtmektedirler. İnternet bağımlılı̆ı ve alışveriş davranışları üzerine yapılan sınırlı sayıda çalışma bu görüyü doğrular sonuçlar sunmaktadır (Sun ve Wu, 2011; Lee Park ve Bryan Lee, 2016; Rose ve Dhandayudham, 2014; Trotzke vd., 2015; Bernardi ve Pallanti, 2009; Patwardhan ve Yang, 2003, Zeren ve Gökdağıı, 2017). Son olarak da dürtüsel bir satın alma davranışı olan 


\section{Volkan Yakın ve Pınar Aytekin}

çevrimiçi anlık satın alma davranışının kompulsif (zorlayıcı) satın alma davranışını tetikleyebileceği düşüncesinden hareketle dördüncü, beşinci ve altıncı hipotezler şu şekilde belirlenmiştir:

H4: İnternet bağımlıı̆ı çevrimiçi anlık satın alma davranışını pozitif yönde etkiler.

H5: İnternet bağımlıı̆ı çevrimiçi kompulsif satın alma davranışını pozitif yönde etkiler.

H6: Çevrimiçi anlık satın alma davranışı, çevrimiçi kompulsif satın alma davranışını pozitif yönde etkiler.

\section{METODOLOJí}

Verilerin toplanması aşamasında internetten alışveriş yapan internet kullanıcılarına kartopu yöntemi ile anket uygulanmıştır. İnternet bağımlıı̆ını ölçmek için Meerkerk, Van den Eijnden, Vermulst ve Garrelsen'in (2009), çevrimiçi anlık satın alma davranışını ölçmek için Park, Kim, Funches ve Foxx'un (2012), çevrimiçi kompulsif satın alma davranışını ölçmek için ise Shanmugam'ın (2011) ölçeklerinden yararlanılmışıı. Pilot çalışma ve doğrulayıcı faktör analizi sonucunda ölçekte uyarlamalara gidilmiştir.

Araştırmanın ana kütlesini Türkiye'de internet üzerinden çevrimiçi alışveriş yapanlar oluşturmaktadır. Türkiye'de çevrimiçi alışveriş yapan kişi sayısı yaklaşık 20 milyondur (Tuik, 2017) ve $N \geq 10.0000 .000$ olduğunda \%95 güvenilirlik düzeyinde $n=384$ yeterli olmaktadır (Sekaran, 2003) bilgisinden hareket ederek toplamda 408 kişiye internet ortamında anket uygulanmış eksik doldurulan 3 anket analiz dışı bırakılarak 405 anket verisi analiz edilmiştir.

Ölçeklere SPSS 25 ve AMOS 22 programlarında sırasıyla tanımlayıcı istatistik analizi, açıklayıcı faktör analizi ve doğrulayıcı faktör analizleri yapılmıştır. Güvenilirlik analizi sonucunda ölçeklerin \%95 güven aralı̆ı̆ında cronbach's alpha değerleri sırasıyla; internet bağımlılığı için 0,926, çevrimiçi anlık satın alma için 0,885 ve çevrimiçi kompulsif satın alma için ise 0,929 olarak tespit edilmiştir. Bu değerler ölçeklerin güvenilirlik düzeylerinin yüksek olduğunu göstermektedir. Elde edilen verilere sırasıyla açıklayıcı (Kaiser-Meyer-Olkin) ve yapısal eşitlik doğrulayıcı faktör analizleri uygulanmıştır. Doğrulayıc faktör analizi sonucunda toplam 34 ifadeden internet bağımlıı̆ını ölçen 4 ifade, belirlenen iki faktöre de yükleme yaptığı için ölçekten çıkarılmıştır. 


\section{İnternet Bağımlılığının Online Kompulsif ve Online Anlık Satın Alma Davranışlarına Etkisi}

\section{BULGULAR VE YORUMLAR}

Tanımlayıcı istatistik analizi sonucunda her bir demografik grubun en sık rastlanan bugularına bakıldığında katılımcıların \%57,33'ünü kadınların, \%53,82'sini üniversite mezunlarının, \%50,12'sini bekarların, $\% 39,5$ 'ini 29-39 yaş aralığındakilerin, \%43,7'sini "4000 TL ve üstü" geliri olanların oluşturduğu belirlenmiştir (Tablo 3 ).

\section{Tablo 3: Tanımlayıcı İstatistik Analizi}

\begin{tabular}{|c|c|c|c|}
\hline & & $\mathbf{N}$ & $\%$ \\
\hline \multirow[t]{2}{*}{ Cinsiyet } & Kadın & 233 & 57,53 \\
\hline & Erkek & 172 & 42,46 \\
\hline \multirow[t]{5}{*}{ Yaş } & $18-28$ & 104 & 25,67 \\
\hline & 29-39 & 160 & 39,5 \\
\hline & $40-50$ & 107 & 26,41 \\
\hline & $>50$ & 34 & 8,38 \\
\hline & & $\mathbf{N}$ & $\%$ \\
\hline \multirow[t]{2}{*}{ Medeni durumu } & Evli & 202 & 49,87 \\
\hline & Bekar & 203 & 50,12 \\
\hline \multirow[t]{6}{*}{ Gelir } & 1000 ve altı & 55 & 13,58 \\
\hline & $1001-2000$ & 39 & 9,62 \\
\hline & $2001-3000$ & 73 & 18,02 \\
\hline & $3001-4000$ & 61 & 15,06 \\
\hline & 4000 ve üstü & 177 & 43,7 \\
\hline & & $\mathbf{N}$ & $\%$ \\
\hline \multirow[t]{7}{*}{ Eğitim durumu } & Okur-yazar & 2 & 0,49 \\
\hline & İlköğretim & 0 & 0 \\
\hline & Ortaokul & 3 & 0,74 \\
\hline & Lise & 43 & 10,61 \\
\hline & Üniversite & 218 & 53,82 \\
\hline & Yüksek lisans & 81 & 20 \\
\hline & Doktora & 58 & 14,32 \\
\hline
\end{tabular}

Ölçeğe uygulanan doğrulayıcı faktör analizi sonucunda, RMR, GFI, RMSEA iyi uyumu gösterirken $x^{2} / S D$, AGFI, NFI, NNFI, CFI kabul edilebilir uyumu göstermektedir (İlhan ve Çetin, 2014). Bu durumda modelin doğrulandığını söylemek mümkündür (Tablo 4). 


\section{Volkan Yakın ve Pınar Aytekin}

Tablo 4: Doğrulayıcı Faktör Analizi

\begin{tabular}{|c|c|c|c|}
\hline \multirow[b]{2}{*}{ İndeks } & \multirow[b]{2}{*}{ Değer } & \multicolumn{2}{|r|}{ Referans* } \\
\hline & & $\begin{array}{l}\text { İyi } \\
\text { Uyum }\end{array}$ & Kabul Edilebilir Uyum \\
\hline$x^{2} / S D$ & 2,295 & $\leq 2$ & $\leq 2-3$ \\
\hline RMR & 0,057 & $\leq 0,05$ & $0,06-1,00$ \\
\hline GFI & 0,951 & $\geq 0,95$ & $0,90-0,95$ \\
\hline AGFI & 0,861 & $\geq 0,90$ & $0,85-0,89$ \\
\hline $\mathrm{NFI}$ & 0,910 & $\geq 0,95$ & $0,90-0,94$ \\
\hline NNFI (TLI) & 0,939 & $\geq 0,95$ & $0,90-0,94$ \\
\hline CFI & 0,951 & $\geq 0,95$ & $0,90-0,95$ \\
\hline RMSEA & 0,057 & $\leq 0,05$ & $0,05-0,08$ \\
\hline
\end{tabular}

Verilerin normal dağılıp dağılmadığı Kolmogorov-Smirnov Testi ile analiz edilmiş, analiz sonucunda anlamlılık değerleri 0,05'den küçük olduğu için normal dağımadığı görülmüştür. Bu nedenle analizler için parametrik olmayan testler kullanmıştır (Kalaycı, 2010). Buna göre; farklılık analizleri için $(\mathrm{H} 1, \mathrm{H} 2, \mathrm{H} 3)$ Mann-Whitney $\mathrm{U}$ Testi ve KruskalWallis $\mathrm{H}$ Testi, davranışların birbiriyle ilişkilerinin analizi içinse $(\mathrm{H} 4, \mathrm{H} 5$, H6) yapısal eşitlik yol analizi testi uygulanmıştır.

Mann Whitney U testi sonucunda; \%95 güvenilirlik düzeyinde, demografik faktörlerden cinsiyet ve medeni duruma göre tüketicilerin internet bağımlııklarının ve çevrimiçi kompulsif satın alma davranışlarının istatistiki açıdan anlamlı bir farklılık gösterdiği ( $\mathrm{H} 1 \mathrm{a}, \mathrm{H} 1 \mathrm{~b}, \mathrm{H} 3 \mathrm{a}, \mathrm{H} 3 \mathrm{~b})$; yine cinsiyet ve medeni duruma göre tüketicilerin çevrimiçi anlık satın alma davranışlarının istatistiki açıdan anlamlı bir farklılık göstermediği saptanmıştır (H2a, H2b). Kruskal-Wallis H Testi sonucunda \%95 güvenilirlik düzeyinde demografik faktörlerden kişisel aylık gelire göre internet bağımlılığı ve çevrimiçi kompulsif satın alma davranışlarında istatistiki açıdan anlamlı bir farklılık olduğu (H1d, H3d); yine kişisel gelire göre çevrimiçi anlık satın alma davranışında istatistiki açıdan anlamlı bir farklılık olmadığı (H2d) görülmüştür. Tüketicilerin yaşlarına göre; internet bağımlıı̆ı, çevrimiçi kompulsif satın alma ve çevrimiçi anlık satın alma davranışlarında istatistiki açıdan anlamlı farklılıklar olduğu belirlenmiştir ( $\mathrm{H} 1 \mathrm{c}, \mathrm{H} 2 \mathrm{c}, \mathrm{H} 3 \mathrm{c})$ Tüketicilerin mesleklerine ve eğitim düzeylerine göre ise; internet bağımlıı̆ı, çevrimiçi kompulsif satın alma ve çevrimiçi anlık satın 


\section{İnternet Bağımlıı̆ının Online Kompulsif ve Online Anlık Satın Alma Davranışlarına Etkisi}

alma davranışlarında istatistiki açıdan anlamlı farklıııklar olmadığı saptanmıştır (H1e, H1f, H2e, H2f, ,H3e, H3f). Mann Whitney U ve Kruskal-Wallis testi sonucunda ret ve kabul edilen hipotezler Tablo 5'de gösterilmiştir.

Tablo 5: Mann Whitney U, Kruskal- Wallis H Testi Sonuçları

\begin{tabular}{|c|c|c|c|c|}
\hline Hipotez & $\begin{array}{l}\text { İnternet } \\
\text { Bağımlılığı } \\
*(p \leq 0,05)\end{array}$ & $\begin{array}{l}\text { Çevrimiçi } \\
\text { Anlık Satın } \\
\text { Alma } \\
*(p \leq 0,05)\end{array}$ & $\begin{array}{l}\text { Çevrimiçi } \\
\text { Kompulsif Satın } \\
\text { Alma } \\
*(p \leq 0,05)\end{array}$ & SONUÇ \\
\hline H1a (Cinsiyet) & $0,038 *$ & & & Kabul \\
\hline $\mathrm{H} 2 \mathrm{a}$ (Cinsiyet & & 0,108 & & Ret \\
\hline H3a (Cinsiyet) & & & $0,017 *$ & Kabul \\
\hline H1b (Medeni D) & $0,000 *$ & & & Kabul \\
\hline H2b (Medeni D) & & 0,117 & & Ret \\
\hline H3b (Medeni D) & & & 0,003* & Kabul \\
\hline H1c (Yaş) & $0,000 *$ & & & Kabul \\
\hline H2c (Yaş) & & $0,014^{*}$ & & Kabul \\
\hline H3c (Yaş) & & & $0,000^{*}$ & Kabul \\
\hline H1d (Gelir) & 0,850 & & & Ret \\
\hline H2d (Gelir) & & $0,001 *$ & & Kabul \\
\hline H3d (Gelir) & & & $0,023 *$ & Kabul \\
\hline H1e(Meslek) & 0,084 & & & Ret \\
\hline H2e (Meslek) & & 0,856 & & Ret \\
\hline H3e(Meslek) & & & 0,106 & Ret \\
\hline H1f (Eğitim) & 0,247 & & & Ret \\
\hline H2f (Eğitim) & & 0,204 & & Ret \\
\hline H3f (Eğitim) & & & 0,137 & Ret \\
\hline
\end{tabular}

Son olarak yapısal eşitlik modellemesi yol analizi testi ile; internet bağımlılığı, çevrimiçi kompulsif satın alma ve çevrimiçi anlık satın alma davranışları arasındaki ilişkiler (H4, H5, H6) açıklanmaya çalışılmışıı (Şekil1). Analizde gözlenen değişkenlerin sahip olduğu özel bir dağılıma ilişkin varsayımlara bakmaksızın tutarlı bir kestiricisinin elde edilmesini sağladığı için ağırıklandırılmamış en küçük kareler metodu kullanıımıştır (Çelik, Saraçlı ve Yılmaz, 2011). Modelin uyum iyiliği değerlerine bakıldığında RMR değerinin 0,055, GFI değerinin 0,992, AGFI değerinin 0,991, CFI değerinin 0,991, NFI değerinin 0,963 ile iyi uyumu gösterdikleri belirlenmiştir (Tablo 6) (İlhan ve Çetin, 2014). Yapısal eşitlik analizi sonucunda internet bağımlıı̆ının çevrimiçi kompulsif ve çevrimiçi 


\section{Volkan Yakın ve Pınar Aytekin}

anlık satın alma davranışı üzerinde; çevrimiçi anlık satın alma davranışının da çevrimiçi kompulsif satın alma davranışı üzerinde pozitif yönde bir etkisi olduğu bulgulanmışıı. Yapısal eşitlik analizi sonucunda internet bağımlılığı ve çevrimiçi anlık satın alma arasında pozitif bir ilişki olduğu, yine internet bağımllığı ve çevrimiçi kompulsif satın alma arasında pozitif bir ilişki olduğu ve anlık satın alma davranışı ile kompulsif satın alma davranışı arasında da pozitif bir ilişki olduğu bulgulanmış ve sonuç olarak $\mathrm{H} 4$, H5 ve $\mathrm{H} 6$ hipotezleri kabul edilmiştir. Değişkenler arasındaki pozitif ilişkileri gösteren oranlar Şekil 2'de yapısal eşitlik analizi sonucu elde edilen sonuç modeli üzerinde görülmektedir.

Tablo 6: Yapısal Eşitlik Analizi Uyum Değerleri

\begin{tabular}{|c|c|c|c|}
\hline \multirow[b]{2}{*}{ İndeks } & \multirow[b]{2}{*}{ Değer } & \multicolumn{2}{|r|}{ Referans* } \\
\hline & & İyi Uyum & Kabul Edilebilir Uyum \\
\hline RMR & 0,055 & $\leq 0,05$ & $0,06-1,00$ \\
\hline GFI & 0,992 & $\geq 0,95$ & $0,90-0,95$ \\
\hline AGFI & 0,991 & $\geq 0,90$ & $0,85-0,89$ \\
\hline NFI & 0,963 & $\geq 0,95$ & $0,90-0,94$ \\
\hline NNFI (TLI) & 0,940 & $\geq 0,95$ & $0,90-0,94$ \\
\hline CFI & 0,991 & $\geq 0,95$ & $0,90-0,95$ \\
\hline
\end{tabular}

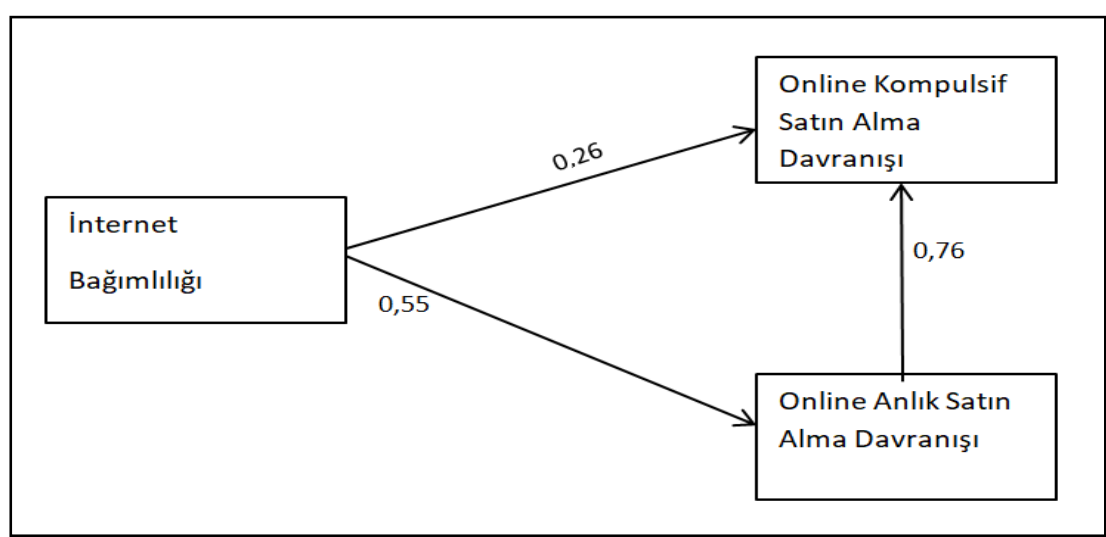

Şekil 2: Yapısal Eşitlik Sonuç Modeli

İnternet bağımlılığı, çevrimiçi kompulsif satın alma ve çevrimiçi anlık satın alma davranışları arasındaki ilişkiler incelendiğinde, internet bağımılı̆̆ının çevrimiçi kompulsif ve çevrimiçi anlık satın alma davranışları 


\section{İnternet Bağımlılığının Online Kompulsif ve Online Anlık Satın Alma Davranışlarına Etkisi}

üzerinde pozitif yönde bir etkisi olduğu belirlenmiştir. $\mathrm{Bu}$, internet ortamında çok fazla zaman geçiren internet bağımlısı kişilerin, alışverişi de internet ortamında yapmaya eğilimli oldukları düşünüldüğünde beklenen bir sonuçtur.

Araştırmada, çevrimiçi anlık satın alma davranışının çevrimiçi kompulsif satın alma davranışı üzerinde pozitif yönde bir etkisi olduğu ulaşılan diğer bir sonuçtur. Kişi, kompulsif satın alma davranışında da anlık satın alma davranışında olduğu gibi dürtüsel bir satın alma güdüsü hissetmekte ve bunu denetleyememektedir. Bu sonucun çıkmasında; bu iki satın alma davranışı arasında odak nokta, etken ve sonuçlar açısından çeşitli farklııklar bulunsa da, satın almanın karşı koyulamayan ya da kontrol edilemeyen bir dürtüyle gerçekleşmesi açısından benzerlikler bulunmasının etkili olduğu düşünülmektedir.

Tüketicilerin demografik özelliklerine göre; internet bağımlı̆ı̆ı, çevrimiçi kompulsif satın alma ve çevrimiçi anlık satın alma davranışları açısından farklııklar incelendiğinde; erkeklerin internet bağımlısı olma olasılı̆̆ının kadınlara göre daha yüksek, kadınların çevrimiçi kompulsif satın alma davranışı gösterme olasılığının ise erkeklere göre daha yüksek olduğu görülmüştür. Literatürde cinsiyet değişkeni ile dürtüsel satın alma davranışı arasındaki ilişkiyi araştıran çalışma sonuçları birbirinden farklılıklar göstermektedir (Awan ve Abbas, 2015; Gohary ve Hanzaee, 2014; Mueller, Claes, Mitchell, Faber, Fischer ve De Zwaan 2011; Shoham ve Makovec Brenčič, 2003). Bekarların internet bağımlısı olma ve çevrimiçi kompulsif satın alma davranışı gösterme olasılığının ise evlilere kıyasla daha yüksek olduğu saptanmışır. Gençlerin internet bağımlısı olma, çevrimiçi anlık satın alma ve çevrimiçi kompulsif satın alma davranışlarını gösterme olasılığının da yetişkinlerden daha yüksek olduğu belirlenmiştir bu sonuç O'Guinn ve Faber (1989a) ve Faber ve O'Guinn (1992)'in araştırma sonuçları ile tutarlıık gösterirken Zeren ve Gökdağı (2017)'nin çalışmaları ile farklıık göstermektedir. Gelir düzeyi düştükçe internet bağımlısı olma ve çevrimiçi kompulsif satın alma davranışı gösterme olasılığının da yükseldiği görülmektedir. Bu sonuç literatürde yer alan diğer araştırma sonuçları ile tutarlılık göstermektedir (Awan ve Abbas 2015; Bashar, Ahmad ve Wasiq, 2013; Rana and Tirthani, 2012).

Bağımlılıkların ve takıntılı davranışların temelinde genel olarak sorunlardan kaçma çabası ve kaygı bozuklukları yer almaktadır. Özellikle internet bağımlıı̆ı söz konusu olduğunda bağımlılığa neden olan faktörlerden birinin de sosyal destek olduğu görülmektedir (Batıgün ve Kılıç, 2011). Analiz sonucunda bu tarz davranışları sergileyen tüketici 


\section{Volkan Yakın ve Pınar Aytekin}

profilinin (ağırlıklı olarak) genç, düşük gelirli ve bekâr kadınlardan oluştuğu görülmektedir. Bunun nedeni; bu tüketicilerin, duygusal birlikteliklerden ya da ilişkilerden yoksun olmalarının yarattığı içsel ve toplumsal baskılar, maddi sıkıntılar gibi kaygılarla baş etmede daha doğru yolları bulmak için yeterli bilgi ve tecrübeye sahip olmamaları olabilir. Diğer taraftan araştırmada internet bağımlılığının gelir, meslek ve eğitim faktörleri açısından anlamlı bir farklıık göstermediği bulgulanmıştır. Bu üç faktör birbirleri ile yakın ilişki içinde olduklarından bağımlıık geliştirme davranışı üzerinde herhangi bir etkileri olmaması yönündeki sonuçların kendi içinde tutarlıık gösterdiği anlaşılmaktadır. Sonuçlar eğitim ve meslek açısından literatürde daha önce Reisch, Gwozdz ve Raab (2012) tarafından yapılan araştırma sonuçları ile tutarlılık gösterirken ülkemizde Arslan (2015) tarafından gerçekleştirilen bir araştırmanın sonuçlarıyla farklılık göstermektedir.

\section{SONUÇ VE ÖNERÍLER}

Günümüzde, sunulan teknolojik kolaylıklar ve dolayısıyla tüketim alışkanlıklarında meydana gelen değişimler kompulsif ve anlık satın alma davranışları için yeni mecralar oluşturmuştur. Kompulsif ve anlık satın alma gibi dürtüsel satın alma davranışlarının internet ortamında yaşanmasıyla, çevrimiçi kompulsif ve çevrimiçi anlık satın alma davranışı şeklinde kavramlar ortaya çıkmıştır. İnternet teknolojilerindeki gelişmeler beraberinde "internet bağımlıı̆ı" gibi çağımızın, insan davranışı üzerinde yıkıc etkilere neden olabilen sorunlarından birini de getirmektedir. Bu çalışmada, internet bağımlılı̆ının çevrimiçi kompulsif ve çevrimiçi anlık satın alma davranışlarına etkisi olup olmadığı belirlemek amaçlanmıştır. Ayrıca; çevrimiçi anlık satın alma davranışının çevrimiçi kompulsif satın alma davranışı üzerindeki etkisi ölçülmeye ve internet bağımllığı, çevrimiçi kompulsif ve çevrimiçi anlık satın alma davranışları açısından tüketicilerin demografik özelliklerine göre farklılıklar olup olmadığı saptanmaya çalışılmıştır.

Araştırma sonucunda; demografik faktörlere göre araştırma konusu değişkenler açısından farkıııklara ilişkin sonuçlara bakıldığında; erkeklerin internet bağımlısı olma eğiliminin kadınlara göre daha yüksek, kadınların çevrimiçi kompulsif satın alma davranışı gösterme eğiliminin ise erkeklere göre daha yüksek olduğu görülmüştür. Bekârların internet bağımlısı olma ve çevrimiçi kompulsif satın alma davranışı gösterme eğiliminin ise evlilere kıyasla daha yüksek olduğu saptanmıştır. Gençlerin internet bağımlısı olma, çevrimiçi anlık satın alma ve çevrimiçi kompulsif satın 


\section{İnternet Bağımlılığının Online Kompulsif ve Online Anlık Satın Alma Davranışlarına Etkisi}

alma davranışlarını gösterme eğiliminin de yetişkinlerden daha yüksek olduğu belirlenmiştir. İnternet bağımllı̆̆ının gelir, meslek ve eğitim faktörleri açısından ise anlamlı bir farklıık göstermediği bulgulanmıştır. Değişkenler arası ilişkilere bakıldığında, internet bağımılığının çevrimiçi kompulsif ve çevrimiçi anlık satın alma davranışları üzerinde pozitif yönde bir etkisi olduğu belirlenmiştir. Çevrimiçi anlık satın alma davranışının çevrimiçi kompulsif satın alma davranışı üzerinde pozitif yönde bir etkisi olduğu araştırmada elde edilen diğer bir sonuçtur.

Kartopu örneklemin anakütleyi temsil gücünün zayıf olması araştırmanın en önemli kısııını oluşturmaktadır. Bu nedenle çalışma sonucunda elde edilen bulguların genellenebilmesi için daha geniş bir örneklem hacmi ile anakütleyi temsil gücüne sahip bir şekilde yeniden uygulanması tüketicilerin çevrimiçi anlık ve kompulsif satın alma davranışlarının anlaşılması açısından katkı sağlayacaktır. Gelecek araştırmalarda çevrimiçi anlık satın alma ve kompulsif satın alma davranışlarına etki edebilecek olan tüketici kişilik özellikleri veya sosyal medya reklamları gibi bağımsız değişkenlere odaklanılması yazına önemli katkılar sağlayabilecektir.

Sonuç olarak çalışmada tüketicilerin kompulsif ve anlık satın alma davranışında bulunmaları ilk bakışta işletmeler açısından karlı bir durum gibi algılansa da, alışveriş sonrası gerçekleşen ürün iadelerinin ve müşteri memnuniyetsizliklerinin ve negatif ağızdan ağıza pazarlamanın daha çok bu şekilde dürtüsel davranışlar gösteren tüketicilerden kaynaklandığı bilinmektedir (Hassay ve Smith, 1996; Kukar-Kinney, Scheinbaum ve Schaefers 2016). Bu nedenle; internet ortamında pazarlama çalışmaları yapmayı düşünen kurum ve kuruluşların, özellikle de sanal ortamda ticari faaliyet gösteren firmaların, çevrimiçi kompulsif ve çevrimiçi anlık satın alma davranışlarının önüne geçecek proaktif yaklaşımlar sergilerken bu

davranışlarda bulunan tüketicilerin demografik özelliklerini dikkate almalarında ve internet bağımlılığının da bu davranışların gösterilmesine neden olan önemli bir etken olduğunu göz önünde bulundurmalarında fayda vardır.

\section{KAYNAKÇA}

Arısoy, Ö. (2009). İnternet Bağımlılığı ve Tedavisi. Psikiyatride Güncel Yaklaşımlar, 1(1), 55-67.

Arslan, B. (2015). Kredi Kartı Kullanımının Kompulsif Satın Almaya Etkisi. AJIT-e: Online Academic Journal of Information Technology, 6(20). 


\section{Volkan Yakın ve Pınar Aytekin}

Awan, A. G., ve Fatima, A. (2014). Impact of Marketing Strategies on youth purchasing behavior: A Case study of Mobile Phone industry. British Journal of Marketing Studies, 2(4), 72-80.

Awan, A. G. ve Abbas, N. (2015). Impact of demographic factors on impulse buying behavior of consumers in multan-pakistan. European Journal of Business and Management, 7(22), 96-105.

Aytekin, P. ve Ay, C. (2015). Hedonik Tüketim ve Anlık Satın Alma: İzmir İlinde Bir Araştırma, Niğde Üniversitesi İktisadi ve İdari Bilimler Fakültesi Dergisi 8(1), 141-156.

Bashar, A., Ahmad, I., ve Wasiq, M. (2013). A Study of Influence of Demographic Factors on Consumer Impulse Buying Behaviour. International Journal of Marketing and Management Research, 4(3and4), 64-76.

Batıgün, A. D. ve Kılıç, N. (2011). İnternet Bağımlılı̆ı ile Kişilik Özellikleri, Sosyal Destek, Psikolojik Belirtiler ve Bazı Sosyo-Demografik Değiş̧kenler Arasındaki İlişkiler Türk Psikoloji Dergisi, 26(67), 1-10.

Bernardi, S., ve Pallanti, S. (2009). Internet addiction: a descriptive clinical study focusing on comorbidities and dissociative symptoms. Comprehensive Psychiatry, 50(6), 510-516.

Bozkurt, H., Şahin, S. ve Zoroğlu, S. (2016). İnternet Bağımllığı: Güncel Bir Gözden Geçirme. Journal of Contemporary Medicine, 6(2), 113.

Caplan, S. E. (2006). Relations Among Loneliness, Social Anxiety, and Problematic Internet Use. CyberPsychology \& Behavior, 10(2), 234-242.

Chen, Y., ve Zhang, L. (2015). Influential Factors for Online Impulse Buying in China: A Model and Its Empirical Analysis. International Management Review, 11(2), 45-51.

CNN Türk (2018). Türkiye'de İnternete Erişim Oranı Yüzde 80'i Geçti, https://www.cnnturk.com/bilim-teknoloji/turkiyede-interneteerisim-orani-yuzde-80i-gecti, (24.07.2018).

Çelik H. E., Saraçlı, S. ve Yılmaz, V., (2011). Yapısal Eştlik Modellemesinde Çok Değişkenli Normallik Varsayımı Altında Bir Uygulama. Physical Sciences, 6(4), 112-123.

Dalal, P. K. ve Basu, D., (2016). Twenty years of Internet addiction... Quo Vadis? Indian Journal of Psychiatry, 58(1), 6-11.

D'Astous, A., Maltais, J. ve Roberge, C., (1990). Compulsive Buying Tendencies of Adolescent Consumers. ACR North American Advances, pp. 306-312. 


\section{İnternet Bağımlılığının Online Kompulsif ve Online Anlık Satın Alma Davranışlarına Etkisi}

Dittmar, H., Beattie, J. ve Friese, S. (1995). Gender identity and material symbols: Objects and decision considerations in impulse purchases. Journal of Economic Psychology, 16(3), 491-511.

Dittmar, H., Long, K. ve Bond, R., (2007). When a Better Self is Only a Button Click Away: Associations Between Materialistic Values, Emotional and Identity-Related Buying Motives, And Compulsive Buying Tendency Online. Journal of Social and Clinical Psychology, 26(3), 334-361.

Dursun, T. ve Yener, D. (2014). İçgüdüsel Satınalma Ölçeklerinin Türk Tüketiciler İçin Uyarlanmasına Yönelik Hazır Giyim Sektöründe Bir Uygulama. Electronic Journal of Vocational Colleges, 22-31.

Faber, R. J. ve O'Guinn, T. C. (1992). A Clinical Screener for Compulsive Buying. Journal of Consumer Research, 19(3), 459-469

Faber, R. J.,ve Christenson, G. A. (1996). In the Mood to Buy: Differences in the Mood States Experienced by Compulsive Buyers and Other Consumers. Psychology \& Marketing, 13(8), 803-819.

Ferraro, G., Caci, B., D'amico, A. ve Blasi, M. D. (2006). Internet Addiction Disorder: An Italian Study. CyberPsychology \& Behavior, 10(2), 170-175.

Gohary, A., ve Hanzaee, K. H. (2014). Personality Traits as Predictors of Shopping Motivations and Behaviors: A Canonical Correlation Analysis. Arab Economic and Business Journal, 9(2), 166-174.

Goldberg I. (1995). IAD, in Cinti M. E.(a cura di) Internet Addiction Disorder un fenomeno sociale in espansione, pp.6, 7, http://www.iucf.indiana.edu/brown/hyplan/addict.html (25.07.2018)

Griffiths, M. (1999). Internet Addiction: Fact or Fiction? The Psychologist, 12(5), 246-250.

Hassay, D. N. ve Smith, M. C. (1996). Compulsive Buying: An Examination of The Consumption Motive. Psychology \& Marketing, 13(8), 741-752.

Hur, M. H. (2006). Demographic, Habitual, and Socioeconomic Determinants of Internet Addiction Disorder: An Empirical Study of Korean Teenagers. Cyberpsychology \& Behavior, 9(5), 514-525.

İlhan, M. ve Çetin, B. (2014). LISREL ve AMOS Programları Kullanılarak Gerçekleştirilen Yapısal Eşitlik Modeli (Yem) Analizlerine İlişkin Sonuçların Karşılaştırılması. Eğitimde ve Psikolojide Ölçme ve Değerlendirme Dergisi, 5(2), 26-42. 


\section{Volkan Yakın ve Pınar Aytekin}

Internet World Stats (2017). Usage Statistics: The Internet Big Picture (World Internet Users and 2018 Population Stats), https://www.internetworldstats.com/stats.htm, (10.08.2018).

Joji, N. A. ve Raveendran. P. T. (2008). Compulsive Buying Behavior in Indian Consumers and Its Impact on Credit Default-An Emerging Paradigm. Indian Institute of Management Kozhikode.

Kalaycı, Ş. (Ed.) (2010). SPSS Uygulamalı Çok Değişkenli İstatistik Teknikleri. Ankara: Asil Yayın Dağııım.

Kim, J., LaRose, R., ve Peng, W. (2009). Loneliness as The Cause and the Effect of Problematic Internet Use: The Relationship Between Internet Use and Psychological Well-Being. CyberPsychology \& Behavior, 12(4), 451-455.

Korur, M.G. ve Kimzan, H. S. (2016). Kompulsif Satın Alma Eğilimi ve Alışveriş Sonrası Pişmanlık İlişkisinde Kontrolsüz Kredi Kartı Kullanımının Rolü: AVM Müşterileri Üzerine Bir Araştırma. Tüketici ve Tüketim Araştırmaları Dergisi, 8 (1), 43-71.

Kukar-Kinney, M., Scheinbaum, A. C., ve Schaefers, T. (2016). Compulsive Buying in Online Daily Deal Settings: An Investigation of Motivations and Contextual Elements. Journal of Business Research, 69(2), 691-699.

Lee, S., Park, J., ve Bryan Lee, S. (2016). The Interplay of Internet Addiction and Compulsive Shopping Behaviors. Social Behavior and Personality: An International Journal, 44(11), 1901-1912.

Lee, Y. J. ve Park, J. K. (2008). The Mediating Role of Consumer Conformity in E-compulsive Buying. Advances in Consumer Research, 35, 387-392.

Lejoyeux, M. ve Weinstein, A. (2010). Compulsive Buying. The American Journal of Drug and Alcohol Abuse, 36(5), 248-253.

Lucas, M. ve Koff, E. (2014). The Role of Impulsivity and of SelfPerceived Attractiveness in Impulse Buying in Women. Personality and Individual Differences, 56, January, 111-115.

Maraz, A., Griffiths, M. D. ve Demetrovics, Z. (2016). The Prevalence of Compulsive Buying: A Meta-Analysis. Addiction, 111(3), 408-419.

Meerkerk, G. J., Van den Eijnden, R. J. J. M., Vermulst, A. A. ve Garrelsen, H. F. L. (2009). The Compulsive Internet Use Scale (CIUS): Some Psychometric Properties. CyberPsychology \& Behavior, 12 (1), 16.

Mueller, A., Claes, L., Mitchell, J. E., Faber, R. J., Fischer, J., ve De Zwaan, M. (2011). Does Compulsive Buying Differ Between Male 


\section{İnternet Bağımlılığının Online Kompulsif ve Online Anlık Satın Alma Davranışlarına Etkisi}

and Female Students?. Personality and Individual Differences, 50(8), 1309-1312.

Muruganantham, G., ve Bhakat, R. S. (2013). A Review of Impulse Buying Behavior. International Journal of Marketing Studies, 5(3), 149.

Norum, P. (2008). The Role of Time Preference and Credit Card Usage in Compulsive Buying Behavior. International Journal of Consumer Studies, 32(3), 269-275.

O'Guinn, T. C. ve Faber, R. J. (1989). Compulsive Buying: A Phenomenological Exploration. Journal of Consumer Research, 16(2), 147-157.

Park, E. J., Kim, E. Y., Funches, V. M., ve Foxx, W. (2012). Apparel Product Attributes, Web Browsing, And E-Impulse Buying on Shopping Websites. Journal of Business Research, 65(11), 15831589.

Patwardhan, P., ve Yang, J., (2003). Internet Dependency Relations and Online Consumer Behavior: A Media System Dependency Theory Perspective on Why People Shop, Chat, and Read News Online. Journal of Interactive Advertising, 3(2), 57-69.

Phau, I. ve Woo, C. (2008). Understanding Compulsive Buying Tendencies Among Young Australians: The Roles of Money Attitude and Credit Card Usage. Marketing Intelligence \& Planning 26(5), 441-458.

Pirog, S. F. ve Roberts, J. A., (2007). Personality and Credit Card Misuse Among College Students: The Mediating Role of İmpulsiveness. Journal of Marketing Theory and Practice 15(1), pp. 65-77.

Rana, S., ve Tirthani, J. (2012). Effect of Education, Income and Gender on Impulsive Buying Among Indian Consumer an Empirical Study of Readymade Garment Customers. Indian Journal of Applied Research Volume, 1.

Rapp, J. (2012). What Brings You Pleasure? The Role of Desire Within The Development of Compulsive Purchasing. Dissertations, Theses, and Student Research from the College of Business, University of Nebraska-Lincoln http://digitalcommons.unl.edu/businessdiss/37 (07.07.2018)

Reisch, L., Gwozdz, W. ve Raab, G.(2012). Compulsive Buying in Denmark. http://openarchive.cbs.dk/handle/10398/8391

Richins, M. L. (1997). Measuring Emotions in The Consumption Experience. Journal of Consumer Research, 24(2), 127-146. 


\section{Volkan Yakın ve Pınar Aytekin}

Rodríguez-Villarino, R., González-Lorenzo, M., Fernández-González, Á., Lameiras-Fernández, M., ve Foltz, M. L. (2006). Individual Factors Associated with Buying Addiction: An Empirical Study. Addiction Research \& Theory, 14(5), 511-525.

Rook, D. W., (1987). The Buying Impulse. Journal of Consumer Research, 14 (2), 189-199.

Rose, S., ve Dhandayudham, A. (2014). Towards An Understanding of Internet-Based Problem Shopping Behaviour: The Concept of Online Shopping Addiction and its Proposed Predictors. Journal of Behavioral Addictions, 3(4), 83-89.

Sally, L. P. M., (2006). Prediction of Internet Addiction for Undergraduates in Hong Kong, Baptist University, Hong Kong, UMI Dissertation Information Service.

Scherhorn, G., Reisch, L. A. ve Raab, G.. (1990). Addictive Buying in West Germany: An Empirical Study. Journal of Consumer Policy, 13(4), 355-387.

Sekaran, U. (2003). Research Methods For Business: A Skill Building Approach. New York: John Wiley\&Sons, Inc.

Servidio, R. (2014). Exploring the Effects of Demographic Factors, Internet Usage and Personality Traits on Internet Addiction in A Sample of Italian University Students. Computers in Human Behavior, 35, 85-92.

Shanmugam, V. K. (2011). An Empirical Examination of Antecedents and Consequences of E-Compulsive Buying Tendencies: The Moderating Roles of Psychological Factors. The University of North Carolina at Greensboro.

Sharif, S. P. ve Khanekharab, J. (2017). Identity Confusion and Materialism Mediate the Relationship Between Excessive Social Network Site Usage and Online Compulsive Buying. Cyberpsychology, Behavior, and Social Networking, 20(8), 494500.

Sharif, S. P. ve Yeoh, K. K. (2018). Excessive Social Networking Sites Use and Online Compulsive Buying in Young Adults: The Mediating Role of Money Attitude. Young Consumers, 19(3), 310-327.

Shoham, A., ve Makovec Brenčič, M. (2003). Compulsive Buying Behavior. Journal of consumer marketing, 20(2), 127-138.

Stern, H. (1962). The Significance of Impulse Buying Today. Journal of Marketing, 26(2), 59-62. 


\section{İnternet Bağımlılığının Online Kompulsif ve Online Anlık Satın Alma \\ Davranışlarına Etkisi}

Sun, T. ve Wu, G. (2011). Trait Predictors of Online Impulsive Buying Tendency: A Hierarchical Ap. Journal of Marketing Theory and Practice, 19(3), 337-346.

Tsai, H. F., Cheng, S. H., Yeh, T. L., Shih, C. C., Chen, K. C., Yang, Y. C., ve Yang, Y. K. (2009). The Risk Factors Of Internet Addiction-A Survey of University Freshmen. Psychiatry Research, 167 (3), 294299.

Trotzke, P., Starcke, K., Müller, A., ve Brand, M. (2015). Pathological Buying Online as A Specific Form of Internet Addiction: A ModelBased Experimental İnvestigation. PloS one, 10(10), e0140296.

TÜİK (2017). Hanehalkı Bilişim Teknolojileri Kullanım Araştırması, http://www.tuik.gov.tr/PreHaberBultenleri.do?id=24862, (05.08.2018).

Verplanken, B. ve Herabadi, A., (2001). Individual Differences in Impulse Buying Tendency: Feeling and No Thinking. European Journal of Personality, 15, 71-83.

Wang, C.C. ve Yang, H., (2008). Passion for Online Shopping: The Influence of Personality and Compulsive Buying. Social Behavior and Personality: An International Journal 36(5), 693-706.

Workman, L. ve Paper, D. (2010). Compulsive Buying: A Theoretical Framework. Journal of Business Inquiry: Research, Education \& Application, 9(1), 89-126.

Young K. S. (1996) Psychology of Computer Use: XL. Addictive Use of The Internet: A Case That Breaks The Stereotype. Psychol Rep;79 (3 Pt 1):899-902

Young K. S. (1998). Internet Addiction: Emergence of A New Clinical Disorder. Cyberpsychology \& Behavior, 1(3), 237-244.

Zeren D. ve Gökdağlı N., (2017). Satın Alma Motivasyonları: Tüketicilerin Sanal Kompülsif Davranışları Üzerine Bir Araştırma. Dumlupınar Üniversitesi Sosyal Bilimler Dergisi, Pazarlama Kongresi Özel Sayısı, 41-55. 